ber Io, in a gathering of pond-water made in this neightourhood and brought home for microscopical examination, a somewhat singular and unusual object presented itself, but : peedily making its way to the sediment at the bottom, it became lo:t to sight. Upon the evening of the I2th, or after the lapse of fully two days, $n$ hile holding the bottle to the light, the same object again appeared, swimming or flying in mid-water with a feculiar jerky movement resembling that of some of the Entomostraca, and for one of which I at first mistcok it. On remcval by means of a dipping-tube to a zoophyte trough for fuller examination, it proved, to my reat surprise, to be one of the small Hymenopterous flies of the Proctotrupid family, and here it continued its active movements, now walking and running upon the bottom and sides of the trough, now flying, as it were, through midwater by the energetic movements of its wings, but apparently making no effort to e cape. Examination thus proving no easy task while living, and fearing the loss of a specimen of habits so unique, I decided upon securing it permanently as a microscopic mount. With a minute description I need not now trouble you, but as neither in Westwood nor in any other of the authorities on such subjects at my command I can fird any record of this singular fact having been hitherto observed, either in connection with the parasitic Hymenoptera or any other similar insects in the perfect state adated apparently to an aërial life alone-that they should quit their natural habitat for so lengthened a sojourn in the water-I would make the inquiry as to whether any like occurrence has been noted by any of your other correspondents.

Stone, October 6

EDWIN POSTOCK

[Our correspondent has had the good furlune to re-discorer in this country the little Hymenopterous insect fcurd almost simultaneously by Sir John Lubbock and Mr. Duchess in 1862, to which the former applied the name Polynema natans (Transactions of Linnean Society, vol. xxiv. part ii. p. 138, 1863). The insect is parasitic in its larval stage in the eggs of dragon-fies. A brief summary (f its peculiarities is given in Lubbock's "Origin and Metamorphoses of Insects" (Macmillan and Co., 1874). More recently Prof. Westwood has : uggested (Transactions of Linnean Society, second series, "Zoology," vol. i. part viii. p. 584,1879 ) that the insect is scarcely a true Polynema, but rather an Anaphes, or the type of a new genus. A true Ichneumon (Agriotypus armatus) has long been krown to be parasitic in caddis-worms, and therefore also aquatic in its habits. - ED.]

\section{Practical Physics for Boys}

In Prof. Parker's very valuable and interesting parer (vol. xxiv. p. 54) 3 he says: "The consequences of setting large classes of young boys to make oxygen, or to take a specific gravity ... each for himself, might prove rather subversive of order than conducive to improvement." It may be interesting to some of your readers to know that at Clifton College we have lately tried the experiment of turning some of our ordinary physic; classes, numbering from twenty-four to thirly bcys, bodily into the physical laboratory, where they work at weighing, measuring, finding specific gravities and such matters, under the control of a single master. The boys work in pairs, each with a little manual of instruction, and each pair with a separate cupboard of cheap apparatus. Two such classes are taken by Mr. Worthington and myself, and we are both agreed that whatever difficulties we may feel, we have none in the matter of discipline. On the contrary, the boys are with scarcely an exception most keen and eager at this work. I understand that similar classes in practical chemistry will shortly be set on foot by $\mathrm{Mr}$. Shenstone in our chemical la boratory.

H. B. JUPP

Clifton College

\section{A New Comet}

I OBSERVED a telescopic comet in Leo on the mornings of Octoter 4, 5, 6, and Io. The rough positions, as I estinated them, were R.A. 9h. 22m., Dec. $16^{\circ}$ N. on the 4 th, and R.A. 9h. $36 \mathrm{~m}$., Dec. $15^{\circ} \mathrm{N}$. on the Ioth. The motion is about $30^{\prime}$ daily eastwards. When the present bright moonlight is gore the comet will be a fairly bright object in the telescope. At the end of the present week it must be looked for immediately preceding $\eta$ Leonis.

When I saw it first, on the morning of October 4 , it look ed like a bright nebula, and I cannot understand how I missed it on the mornings of September 29 and October I, when $I$ had carefully swept the same region for several hours before sunrise. The inference is that it is getting brighter. W. F. DenNis Ashley-Down, Bristol, October Io

\section{A Kinematical Theorem}

SOME little time ago Mr. Kempe published in NATURE a theorem of interest in kinematics. I subsequently stated in the same pages that this theorem atd all theorems of uniplanar kinematics are most simply and properly proved from the consideration that epicycloidal motion is the basis of all uniplanar motion-and that this is also the proper principle on which to base the theory of planimeters. It may not be out of place to occupy a few lines in NATURE $\mathrm{nith}$ another curious kinematical theorem allied to Kempe's, which I have just found by this method. If a plane, A, move aboul in any manner over a fixed plane, B, and return to its original position after any number of revolutions, all those right lines in the plane A which have enveloped glisettes of the same area, are tangents to a conic, and by varying the area of the glisette we obtain a series of confocal conics. I use the term griseite under protest-" "line roulette" would be better, as the former name is more applicable to a curve of another sort.

royal Indian Engineering College

\section{Integrating Anemometer}

My attertion was calle $d$ to a letter on this subject in ycur issue of the 29th ult. (vol. xxiv. p. $5 \mathrm{IO}$ ), though not in time to enable me to answer it last week. I take this ofportunity of stating that the gentleman to whom the idea of the instrument was originally due, and who has defrayed the whole cost of its construction, is the Rev. J. M. Wilson, M.A., head-master of Clifton College (not Dr. Wilson, as mis-stated in the Association fournal at York and in your abstract). The objection that the air does not move "paraliel to itself," by which I presume is meant in planes parallel to its general direction, does not afply to this any more than to any other cup anemometer. Only the horizontal component of the wind's velocity is sought, and this is given with tolerable accuracy. I have no means of knowing to what extent Mr. Burton's integrator resembles the anemometer in question, but it should be noticed that the two instruments are of a different kind and for a different purpose. Mr. R. Scutt was in the chair when the paper was read at York, and joined in the discussion. Prof. Stokes was also present, and has since been in correspondence with me on the matter. Neither of these gentlemen, however, mentioned any other instrument as at all resembling it ; indeed upon its being compared to that of Dr. von Oetlinger, Mr. Scott took occasion to point out at least one important difference, viz. the cost. H. S. HeIE SHAW

University College, Bristol, October ro

\section{Infusorial Parasites on Stickleback}

Mr. N. H. Poole (NATURF, vol. xxiv, p. 485) is apparently right in anticipating that he has discovered either a new habitat for Trichodina pediculis or a new representative of that infusorial genus. Althounh hitherto regarded as a parasite only of the fresh-water polypes, Hydra vulgaris and H. viridis, I have recently obtained specimens of the type in question living as a parasite, or rather a commensal, on the branchial appendages of the larva of the common newt, Triton cristatus. An allied, but marine species, Trichodina scortana, has been recently descrit ed by Prof. Ch. Robin, that infests in a similar manner the branchia of fishes belonging to the genera Trigla and Scorpena, and a further search will no doubt reveal a yet more extensive distribution of the Urceolaridx, including Trichodina, among the Piscine race. Mr. Poole will find full particulars of the data here referred to, together with an account and illustrations of all the forms so far relegated to this somew hat remarkable infusorial gr up, in Part V., p. 645 ct seq., of my "Manual of the Infusoria," just published.

\section{The Dark Day in New England}

REFERRING to your paragraph in last week's NATURE (p, 540) about the remarkable phenomenon which occurred in New England on September 6, I find in the recently-published "History of Lynn, Massachusetts," the following:-

"I716.-Exiraordinary darkness at ncor day October 21st; dinner tables lighted."

"I 780 .-Memorable dark day May I9th; bouses lighted as at night."

Lynn, October 7 